4. Schinz H., Ruzicka L., Seidel C. F., Helv. Chim. Acta, 30, 1810 (1947).

5. Л э э т с K. В., ЖОХ, 28, 1823 (1958).

6. Gildemeister E., Hof fmann Fr., Die ätherischen Ole, Band II, Berlin, 1960, S. 287.

$\begin{array}{cc}\text { Ннститут химии } & \text { Поступнла в редакцию } \\ \text { Академии наук Эстонской ССР } & 22 / \mathrm{X} 1974\end{array}$

EESTI NSV TEADUSTE AKADEEMIA TOIMETISED, 24, KOIDE KEEMIA * GEOLOOGIA. 1975, NR. 4

ИЗВЕСТИЯ АКАДЕМИИ НАУК ЭСТОНСКОИ ССР. ТОМ 24 ХИМИЯ * ГЕОЛОГИЯ. 1975 , Ае 4

M. KALJURAND, E. KULLIK, L. ESS

удК $543.54681 .3: 5$

\title{
RESOLUTION ENHANCEMENT OF OVERLAPPED GAS CHROMATOGRAPH PEAKS
}

\begin{abstract}
М. КАЛЬЮРАНД, Е. КЮЛЛИК, Л. ЭСС. РАЗДЕЛЕНИЕ ПЕРЕКРЫВАЮЩИХСЯ ГАЗО. ХРОМАТОГРАФИЧЕСКИХ ПИКОВ
\end{abstract}

M. KALJURAND, E. KOLLIK L. ESS. KATTUNUD GAASIKROMIATOGRAAFILISTE PIIKIDE LAHUTAMINE

This paper deals with the application of the Fast Fourier Transformation (FFT) method for measuring overlapped peaks area in gas chromatography.

Mathematical data handling of signal obtained from analytical instruments utilizing Fourier Transformation (FT) has found wide practical application in spectroscopy [ $\left.{ }^{1}\right]$. Data handling of signals utilizing FT is not new, but thanks to the Fast Fourier Transformation the method is beginning to spread. The theory of FFT deconvolution is presented by Kirmse and Westerberg $\left.{ }^{2}\right]$. In this paper we discuss some differences and practical aspects derived from their paper. In quantitative gas chromato. graphy, the exact determination of the peak area is very important. When handling gas chromatogram data, we are often faced with problems where two or more peaks are partially overlapped or the peak's shape assumes the existence of two or more peaks.

The advantages of described method are those that there is no need to point out previously the approximate value of the peak width at half height and the approximate position determination of amplitude maximum like when using the least-square fitting method $\left[{ }^{3}\right]$. The method enhancement consists in indicating previously only the function of peak shape and the approximate value of peak width at half-height of the narrowest peak.

\section{Experiment and results}

The work described in this paper was carried out on a Perkin-Elmer mod. 900 gas chromatograph connected with analog to digital converter (AKM-1) and data punch (TPR-4).* The FFT was calculated on a Videoton

* AKM-1 and TPR-4 are made at the Academy of Sciences of the Estonian SSR. 
1010B computer (16K, 32bit). The FFT and deconvolution programs were written in 1010B Fortran's version. A standard solution of four hydrocarbons $\left(\mathrm{C}_{6}-\mathrm{C}_{9}\right)$ was prepared (weighing accuracy $10^{-4} \mathrm{~g}$ ) and separated in gas chromatograph using flame ionization detector. The separating conditions were chosen so that at the beginning the temperature of the column oven was $90^{\circ} \mathrm{C}$ and all the $\mathrm{C}_{6}-\mathrm{C}_{9}$ hydrocarbon peaks were completely separated.

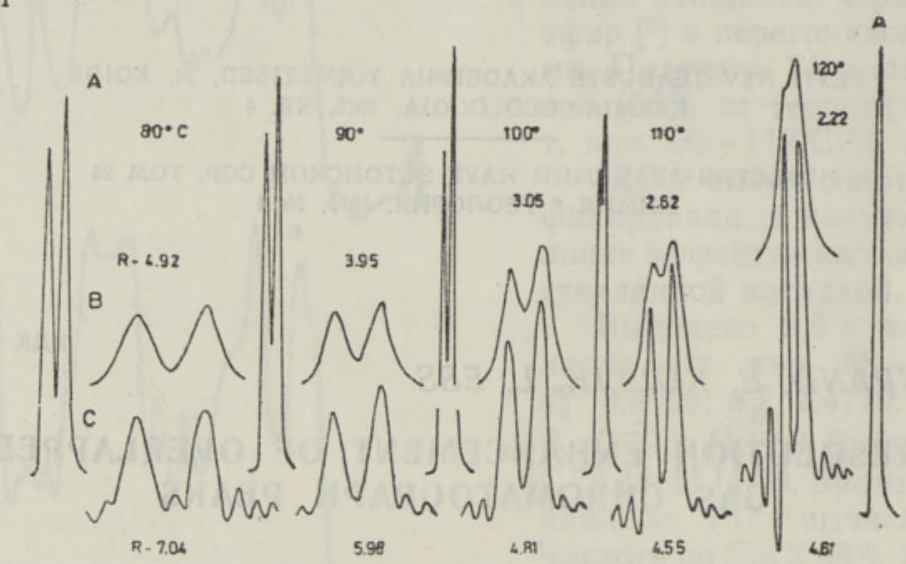

Fig. 1. $A-$ recorder output, $B-$ analog to digital converter output, $C-$ FFT deconvoluted chromatograms.

Assume the peak shapes are Gaussian, then use the well-known equation

$$
y(t)=A e^{-\frac{\left(t-t_{t}\right)^{2}}{2 \sigma_{t}^{2}}}
$$

where $y(t)$ is the value of gas chromatograph's output signal,

$$
\begin{aligned}
& t \text { - time, } \\
& t_{i} \text { - retention time, } \\
& \sigma_{i} \text { - peak width characterization, } \\
& A \text { - peak height at maximum. }
\end{aligned}
$$

For the estimation of the approximate value of $\sigma_{i}$ we can use the common approximate linear connection between $\sigma_{i}$ and $t_{i}$;

$$
\sigma_{i}=\alpha t_{i}+\beta
$$

where $\alpha$ and $\beta=$ const. For the determination of the value of $\alpha$ and $\beta$ we need at least two completely separated peaks which in this case are $C_{b}$ and $\mathrm{C}_{9}$.

The value of accuracy for FFT deconvolution was $C_{7}$ and iso- $C_{8}$ peak's area ratio before and after FFT handling, compared with weighed ratio $\left(\frac{\mathrm{C}_{7}}{\text { iso- }_{8}}=1,04\right)$.

The peak area before FFT was determined using digital integration and perpendicular drop. Equation 2 gives a possibility to calculate the peak area after FFT.

$$
S=\sqrt{2 \pi} \sigma A
$$

Knowing the peak width and the location of the peak maximum which 
were determined with high precision in the Fourier domain, we get the peak resolution

$$
R=\frac{2\left(t_{1}-t_{2}\right)}{\sigma_{1}+\sigma_{2}} .
$$

Fig. $1 A$ shows the $C_{7}$ and iso- $C_{8}$ gas chromatograms of the peaks obtained by using variable oven temperature. At $120 \mathrm{C}$ both peaks are practically overlapped, and the determination of the peak area is not possible. We get principally the same picture by using an analog to digital converter output $1 B$. Fig. $1 C$ shows the same peaks after the FFT. The plot contains 128 points. It shows that FFT sharpening may split an almost overlapped peak into two peaks, and this treatment enables to estimate the peak area ratio and retention time. At the same time the side band intensity increases and the overlapping of peaks decreases. The accuracy of the peak area which depends on the resolution is shown in Fig. 2. We can see that the FFT deconvolution gives more accurate results than the resolution using perpendicular drop (commonly used with integrators).

Taking into consideration that the

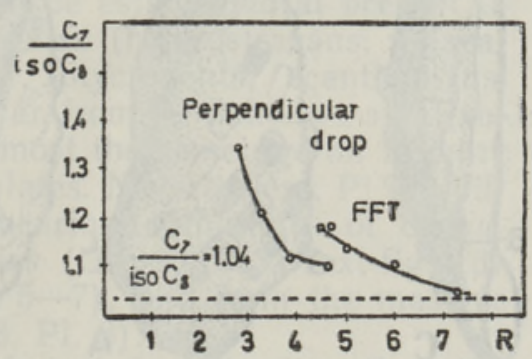

Fig. 2. The difference of peak areas ratio before and after FFT from the real weighed value.

FFT resolution compared with / other

methods gives more possibilities and determines more accurately the peak retention time and areas, the FFT data handling in gas chromatography is very helpful.

\title{
REFERENCES
}

1. Horlick G., Anal. Chem., 44, 943 (1972).

2. Kirmse W. D., Westerberg A. W., Anal. Chem., 43, 1035 (1971).

3. Fr a ser R. D. B., S uz u ki E., Anal. Chem., 38, 1770 (1966). Academy of Sciences of the Estonian SSR,
Institute of Chemistry
Received

Feb. 13, 1975

\author{
EESTI NSV TEADUSTE AKADEEMIA TOIMETISED, 24, KOIDE \\ KEEMIA * GEOLOOGIA. 1975, NR. 4 \\ ИЗВЕСТИЯ АКАДЕМИИ НАУК ЭСТОНСКОИ ССР. ТОМ 24 \\ ХИМИЯ * ГЕОЛОГИЯ. 1975, № 4
}

удК $567: 551.734(571.586)$

Elga MARK-KURIK

\section{A TOOTH-PLATE FROM THE LOWER DEVONIAN OF KOTELNY ISLAND}

ElRa MARK-KURIK. HAMBAPLAAT KOTELNOI SAARE ALAMDEVONIST

ЭЛЬこ М МАК-КУРИК. ЗУБНАЯ ПЛАСТИНКА ИЗ НИЖНЕГО ДЕВОНА ОСТРОВА КОТЕЛЬНОГО

Among the Early Devonian vertebrate remains collected in the Sokolova locality, Kotelny Island, New Siberian Archipelago (see Mark-Kurik, 1974), a peculiar small tooth-plate is of much interest. It has been found 